\title{
Commentary
}

\section{The importance for journals to publish commentaries and letters to the editor in the age of COVID-19}

\author{
Jaime A. Teixeira da Silva*
}

Ikenobe, Kagawa-ken, Japan

Received: 11 February 2021

Revised: 08 April 2021

Accepted: 20 April 2021

\section{*Correspondence:}

Dr. Jaime A. Teixeira da Silva,

E-mail: jaimetex@yahoo.com

Copyright: (c) the author(s), publisher and licensee Medip Academy. This is an open-access article distributed under the terms of the Creative Commons Attribution Non-Commercial License, which permits unrestricted non-commercial use, distribution, and reproduction in any medium, provided the original work is properly cited.

\section{INTRODUCTION}

Some journals do not allows authors' opinions to be published via letters to the editor (L2Es) and/or commentaries. This paper offers an explanation why these two important forms of scholarly communication are fundamental in the COVID-19 era. The open encouragement of the use of L2Es by editors sends a resoundingly positive voice of hope and optimism in a time of the COVID-19 pandemic when doubt, suspect editorial policies, and increasing cases of erroneous literature place a stress test on the integrity of journals, the literature they publish, and on the entire biomedical science scientific publishing enterprise. ${ }^{1,2}$ L2Es thus allow potential misinformation that exists in the media, social media or in the public domain to be debated and corrected within an academic context

Academic journals, and their editors, have the full right to determine the scope, manuscript type, editor board, policies and ethical guidelines for their own journal for one simple reason: they have complete editorial independence. ${ }^{4}$ Yet, with that independence, comes stringent scrutiny and considerable responsibilities. ${ }^{5}$ In a global publishing landscape, there is increasing pressure not only to ensure that journals and their editors assume greater responsibility for what they publish, but to ensure that the integrity of what they publish is sound. This is not always the case, and by the intrinsic nature of human-based weaknesses of the peer review process and biases, the literature may be error-prone and faulty, poorly vetted or otherwise limited in its perspectives. ${ }^{6}$

\section{ACADEMIC FUNCTIONS OF LETTERS TO THE EDITOR AND COMMENTARIES}

It is here that L2Es serve as a post-publication complement of peer review, even years after a paper has been published, to expand the debate on erroneous findings that were not detected during peer review, or different findings that might have emerged after peer review, but that might still be worthy of debate within the journal's confines. ${ }^{7,8}$ Since L2Es tend to be short, typically about 500 words with a handful of references, they may fortify a journal's content by supplementing new ideas, such as floating new hypotheses, while agreeing - or not - with stated hypotheses in a published paper, expanding scientific discourse beyond the confines of a published paper's boundaries while also adding an element of scholarly diversification. ${ }^{9-13}$

To reduce censorship and editorial bias, scientific inquiry and scholarly dialogue are fortified when L2E-based channels of open discussion exist within a moderated scholarly environment that allows for "pointed, constructive, critical dialogue". ${ }^{14,15}$ The tone of a L2E should generally be respectful, and should not be pejorative or biased, elements that editors should work towards eliminating prior to publication. ${ }^{16}$ Rogers et al found that commentaries about PubMed-indexed clinical research papers tended to be more supportive of prior publications while L2Es failed their mission to some extent as a mechanism of critical appraisal. ${ }^{17}$ Unlike anonymous sources, which may be used in journalism, even though they carry risk, anonymous L2Es should not be allowed 
since authors of L2Es, like authors of the papers they critique, need to be held accountable for what they have written. $^{18,19}$ In some cases, multiple L2Es might be published in response to a paper while more rarely, readers and editors can debate in a coordinated and responsive manner within the same L2E. ${ }^{20,21}$

Occasionally, readers of papers with limitations might wish to comment officially, i.e. as a published comment, opinion, or L2E, on a published paper. L2Es, unlike longer commentaries, tend to be short, coherent, objective and clear. ${ }^{22}$ Very importantly, L2Es allow readers, academics and the public to hold a journal accountable for what it has published. ${ }^{23}$ In theory, they should have that right, but in practice, this is not always the case, and it is not uncommon to find journals that do not allow for the publication of manuscript types such as L2Es, where the findings of papers in their journal can be challenged, or where an alternative perspective (commentary) that does not necessarily challenge a paper's findings, but rather enriches them, is allowed. ${ }^{24}$ This is unfortunate for several reasons: it truncates open debate about a published paper at the post-publication stage; it establishes that a discussion is finite, and cannot be challenged indefinitely; if editorials are allowed but not L2Es, it establishes an actual or perceived two-tiered level of expression, one superior (allowed exclusively for editors) and one inferior (not allowed for readers or other academics); it interferes with freedom of speech by not allowing potentially valid opinions to be fairly expressed; it establishes a wall of opacity and shuns transparency; and it reduces the lines of evidence that are essential for scholarly dialogue.

\section{THE OPEN WAY FORWARD}

This paper argues that journals have a scholarly and ideological responsibility to allow academics and others to publish counter-opinions, challenges and broader perspectives in their journal, in the form of short L2Es or longer commentaries. Academics should not be forced to challenge ideas that were published in an academic paper on social media or blogs simply because a journal does not provide a suitable or sufficiently robust platform for challenge and discussion. Naturally, the acceptance of a L2E is not automatic and arguments underlying the rejection must be clearly and logically formulated, while its content needs to be as strictly vetted as regular peerreviewed and/or data-based articles. Rejections need to be fair, and should not be based on differences of opinion alone, since, by their nature, L2Es and commentaries carry bias, nor should they be based on space limitations if their content has value. Rather, rejections of L2Es should be based on fair academic arguments or the display of fundamental flaws, although the publication of L2Es that call out flaws do not always result in an improvement of the literature they call out. ${ }^{25}$ Finally, the acceptance or desk rejection of a L2E should be swift since they are usually limited to a few hundred words that can be screened within a few hours or days, at most. ${ }^{26}$
A message needs to be sent to biomedical journals that do not publish L2Es and commentaries: rethink your editorial policies to accommodate these forms of scholarly dialogue and expression to allow for an equal-minded open and transparent approach to commentary and critique, even more so when critical analysis is needed, not only of COVID-19 literature, but all social, biomedical and healthcare papers. Authors should also be aware that under the current flood of COVID-19-related papers, that editors are also under pressure, and even L2Es, despite their brevity, can compound the pressure to effectively process information in their journal. ${ }^{27}$

\section{REFERENCES}

1. Zaric GS. Welcome message from the new editor. Health Care Manage Sci 2020;23(1):1.

2. Teixeira da Silva JA, Bornemann-Cimenti $H$, Tsigaris P. Optimizing peer review to minimize the risk of retracting COVID-19-related literature. Med Health Care Philos 2021;24(1):21-6.

3. Teixeira da Silva JA. Misinformation in COVID-19 media and literature, with an emphasis on open data policies. J Advocacy Res Edu. 2020;7(2):25-9.

4. Davis RM, Müllner M. Editorial independence at medical journals owned by professional associations: A survey of editors. Sci Eng Ethics. 2002;8:513-28.

5. Teixeira da Silva JA, Dobránszki J. Problems with traditional science publishing and finding a wider niche for post-publication peer review. Account Res. 2018;22(1):22-40.

6. Teixeira da Silva JA, Dobránszki J. Editors moving forward: stick to academic basics, maximize transparency and respect, and enforce the rules. Recenti Progressi Med. 2015;109(5):263-66.

7. Falavarjani KG, Kashkouli MB, Chams H. Letter to editor, a scientific forum for discussion. J Curr Ophthalmol. 2016;28(1):1-2.

8. Baethge C, Seger G. Our readers' voice. Deutsches Ärzteblatt Int. 2009;106(12):207-9.

9. Peh WCG, Ng KH. Writing a letter to the editor. Singapore Med J. 2010;51(7):532-5.

10. Tierney E, O'Rourke C, Fenton JE. What is the role of 'the letter to the editor'? Eur Arch Oto-RhinoLaryngol. 2015;272(9):2089-93.

11. Salcido R. A new policy on letters to the editor. Adv Skin Wound Care. 2003;16(1):4-5.

12. Berquist TH. Professionalism in biomedical publishing: modifications in letters to the editor? Amer J Roentgenol. 2014;202:701-2.

13. Jadhav S, Bavdekar SB. Letter to editor: keeping the dialogue going. J Assoc Phys India. 2015;63(5):55-7.

14. Pless B. Are editors free from bias? The special case of letters to the editor. Injury Prevent. 2006;12(6):353-4.

15. Kearney MH. Write to me please: the scholarly importance of letters to the editor. Res Nursing Health. 2015;38(5):327-9.

16. Süer E, Yaman Ö. How to write an editorial letter? Turkish J Urol. 2013;39(1):41-3. 
17. Rogers JR, Mills H, Grossman LV, Goldstein A, Weng C-H. Understanding the nature and scope of clinical research commentaries in PubMed. J Amer Med Informatics Assoc. 2020;27(3):449-56.

18. Wintterlin F. Trust in distant sources: An analytical model capturing antecedents of risk and trustworthiness as perceived by journalists. Journalism. 2020;21(1):130-45.

19. Reader B. An ethical "blind spot": problems of anonymous letters to the editor. J Mass Media Ethics. 2005;20(1):62-76.

20. Martin C. Commentaries and letters to the editor of The Plant Cell. Plant Cell. 2012;24:3172-3.

21. Teixeira da Silva JA, Blatt MR. Does the anonymous voice have a place in scholarly publishing? Plant Physiol. 2016;170(4):1899-902.

22. Papanas N, Georgiadis GS, Maltezos E, Lazarides MK. Letters to the editor: definitely not children of a lesser god. Int Angiol. 2009;28(5):418-20.

23. ICMJE (International Committee of Medical Journal Editors). Recommendations for the conduct, reporting, editing, and publication of scholarly work in medical journals. 2019. Available at http://www.icmje.org/icmje-recommendations.pdf. Accessed on 08 April 2021.

24. Dkhar SA. Letter to editor: its importance and drawbacks. Int J Community Med Public Health. 2018;5(19):4634-6.

25. Kastner M, Menon A, Straus SE, Laupacis A. What do letters to the editor publish about randomized controlled trials? A cross-sectional study. BMC Res Notes. 2013;6:414.

26. Teixeira da Silva JA, Al-Khatib A, Katavić V, Bornemann-Cimenti H. Establishing sensible and practical guidelines for desk rejections. Sci Eng Ethics. 2018;24(4):1347-65.

27. Ring J. Steering a scientific journal in the age of a publication deluge: a perspective of an Editor-inChief. J Eur Acad Dermatol Venereol. 2020;34(4):666-7.

Cite this article as: Teixeira da Silva JA. The importance for journals to publish commentaries and letters to the editor in the age of COVID-19. Int J Community Med Public Health 2021;8:3725-7. 